\title{
INFLUENCE OF N-P-K FERTILIZATION AT THE ACCLIMATIZATION STAGE ON MICROPROPAGATED SEEDLINGS OF Tillandsia bulbosa Hook
}

\author{
INFLUÊNCIA DA ADUBAÇÃO COM N-P-K NA FASE DE ACLIMATIZAÇÃO \\ EM MUDAS MICROPROPAGADAS DE Tillandsia bulbosa Hook
}

\author{
Maria de Fátima ARRIGONI-BLANK ${ }^{1}$; Márcia Raquel Moura VASCONCELOS ${ }^{2}$; \\ Rosana Barroso FEITOSA-ALCANTARA ${ }^{\mathbf{3}}$; Maria Aparecida MOREIRA ${ }^{\mathbf{1}}$; \\ Evaristo Mauro de CASTRO ${ }^{4}$; Arie Fitzgerald BLANK ${ }^{1}$
}

1. Professor, Doutor, Departamento de Engenharia Agronômica, Universidade Federal de Sergipe - UFS, SE, Brasil. fatima.blank@gmail.com; 2. Mestre em Agricultura e Biodiversidade, UFS, SE, Brasil; 3. Doutora em Biotecnologia, UFS, SE, Brasil; 4. Professor, Doutor, Departamento de Biologia, Universidade Federal de Lavras - UFLA, MG, Brasil.

\begin{abstract}
Bromeliads are known worldwide for their ornamental potential. In Brazil, species of the genus Tillandsia occur in the Atlantic rainforest, Amazon rainforest, and rocky fields. This work aimed to evaluate the influence of nitrogen, phosphorus, and potassium fertilization on micropropagated seedlings of Tillandsia bulbosa, at the acclimatization stage, and their leaf anatomy. The experiment was carried out in a completely randomized design, in a $4 \times 4+1$ factorial scheme, using coconut coir: earthworm humus: sand mixture as substrate (2:1:1). Urea, single superphosphate, and potassium chloride were used as nitrogen, phosphorus and potassium sources, respectively, at proportions of 50, 100, 200, and 400\% of the dose recommended. The doses were distributed in four applications, testing total application at planting (1); $1 / 2$ application at planting and $1 / 2$ at 80 DAP (2); $1 / 3$ application at planting, $1 / 3$ at 50 DAP, and $1 / 3$ at 100 DAP (3); and $1 / 4$ application at planting, $1 / 4$ at 30 DAP, $1 / 4$ at 60 DAP, and $1 / 4$ at 120 DAP (4); and a control (without fertilization). Leaves anatomy was analyzed at 180 days after planting. Fertilization did not significantly influence the development of seedlings during acclimatization. The doses of 50, 100, and $200 \%$ provided thicker parenchyma of chlorophyll and aquifer and leaf blade. Tillandsia bulbosa can be acclimatized without fertilizer application.
\end{abstract}

KEYWORDS: Bromeliaceae. Tissue culture. Fertilizer. Leaf anatomy

\section{INTRODUCTION}

The Bromeliaceae family is one of the largest plant families in Brazil, with 3,172 species subordinated to 58 genera. These plants occur in the Atlantic rainforest, Amazon rainforest, and rocky fields (MARTINELLI et al., 2008; RIBEIRO et al., 2009). The arrangement of the leaves in rosette allows the accumulation of water and debris in the central cavity, known as cistern. These morphological traits contribute to the nutrition of these plants (BENZING, 2000; SIMPSON, 2006).

The genus Tillandsia includes about 550 species of highly variable plant architecture, with plant height ranging from $1 \mathrm{~m}$ to small epiphytes of about $3 \mathrm{~cm}$ (TILL, 2000). Species of this genus are widespread in the Bromeliaceae distribution area, being responsible for the vast geographic range of this family (BENZING, 2000).

The leaves of Tillandsia usually present trichomes, whose function is to absorb water and nutrients. Moreover, environmental conditions, such as water and light, can influence the leaf anatomy at the first developmental stages until the adult stage, modifying its morphology, anatomy, and physiology (CASTRO et al., 2009; OLIVEIRA et al., 2012).
One stage of micropropagation is known as acclimatization, which is the period when seedlings are transferred from the in vitro to the ex vitro environment. At this stage, the seedlings will be gradually exposed to a new environmental condition, which is a critical stage for their survival (BATAGIN et al., 2009).

The substrates used at the acclimatization stage must be suitable for the species, and when necessary, fertilizers must be applied. Chemical fertilization in bromeliads is commonly used, and pineapple (Ananas comosus) is the most studied species regarding this procedure (AMARAL et al., 2009). The nutrients most employed in the chemical fertilization process are nitrogen, phosphorus, and potassium, which must be applied according to the requirements of each crop and the fertilization methodology employed (LONE et al., 2010).

In light of the foregoing, the objective of this work was to verify the influence of nitrogen, phosphorus, and potassium fertilization in micropropagated seedlings of Tillandsia bulbosa by analyzing leaf anatomy at the acclimatization stage. 


\section{MATERIAL AND METHODS}

In vitro seedlings established for approximately 120 days in basic MS medium (MURASHIGE and SKOOG, 1962) were removed from the flasks, washed in running water to eliminate the culture medium adhered to the roots, and transferred to $1.00 \mathrm{~L}$ plastic pots for the fertilization treatments. The substrate used was composed of coconut coir, earthworm humus, and sand $(2: 1: 1)$. The following chemical characteristics of the substrate were evaluated: $\mathrm{pH}$ in water $=6.58$; $\mathrm{P}$ and $\mathrm{K}\left(\mathrm{mg} \mathrm{dm}^{-3}\right)=347$ and $200 ; \mathrm{Ca}^{2+}, \mathrm{Mg}^{2+}, \mathrm{Al}^{3+}$, $\mathrm{H}^{+}, \mathrm{Al}, \mathrm{Ca}^{+}, \mathrm{Mg}\left(\mathrm{cmolc} \mathrm{dm}^{-3}\right)=6.88 ; 2.93 ; 0.08$; 1.63 ; 9.81 ; base saturation V $(\%)=86.9$; organic matter $\left(\mathrm{g} / \mathrm{dm}^{-3}\right)=37.5$. Seedlings were kept in a greenhouse covered with $50 \%$ shading screen and intermittent misting system.

Due to the lack of fertilization recommendation studies for $T$. bulbosa, doses were estimated based on the general recommendation for pot experimentation in greenhouse tests, according to Malavolta (1980). The fertilizer was prepared by mixing $300 \mathrm{mg}$ of N, $200 \mathrm{mg}$ of $\mathrm{P}$, and $200 \mathrm{mg}$ of $\mathrm{K}$ per $\mathrm{dm}^{3}$ of substrate. Urea, single superphosphate $\left(\mathrm{P}_{2} \mathrm{O}_{5}\right)$, and potassium chloride $\left(\mathrm{K}_{2} \mathrm{O}\right)$ were used as nitrogen, phosphorus, and potassium sources, respectively.

The experiment consisted of a completely randomized design, in a $4 \times 4+1$ factorial scheme, with four fertilizer concentrations $(50,100,200$ and $400 \%$ ), in four split applications, via soil [total planting (1); $1 / 2$ at 80 days after planting (DAP) (2); $1 / 3$ at planting, $1 / 3$ at $50 \mathrm{DAP}$, and $1 / 3$ at $100 \mathrm{DAP}(3)$; $1 / 4$ at planting, $1 / 4$ at 30 DAP, $1 / 4$ at 60 DAP, and $1 / 4$ at 120 DAP) (4), and a control (without fertilization)], with four replications and two seedlings per replication. At 180 days after planting, the following variables were analyzed: seedlings survival percentage, seedlings height, number of leaves, dry weight of shoot, vascular bundle area, abaxial and adaxial epidermis thickness, abaxial and adaxial cuticle thickness, aquifer parenchyma thickness, chlorophyll parenchyma thickness, and leaf blade thickness.

For the leaf anatomy study, leaves were collected at 180 days after planting and were subsequently were with FAA 50\% (JOHANSEN, $1940)$ and preserved in $50 \%$ ethanol $(\mathrm{v} / \mathrm{v})$. Anatomical analyses were performed on the middle third of the completely-expanded leaves from the apex, according to the methodology described by Kraus and Arduin (1997). Afterward, the material was placed in activated resin for infiltration.
The infiltrated seedling fragments were placed in histomold ${ }^{\circledR}$, at $37{ }^{\circ} \mathrm{C}$. The embedded seedling material was cut using a semiautomatic microtome LEICA RM 22235, in cross sections with $\pm 7 \mu \mathrm{m}$ thickness. The sections were stained with $0.05 \%(\mathrm{v} / \mathrm{v})$ toluidine blue at $\mathrm{pH} 4.8$, followed by washing with distilled water. After drying, the slides were mounted using stained glass. The slides were observed under an optical microscope equipped with LEICA DM500 capture system. Anatomical analyses were performed using the UTHSCSA Image Tool (University of Texas, San Antonio, USA).

Five cross sections of $T$. bulbosa were evaluated for each stage of the experiment. Results were subject to analysis of variance (ANOVA), and when significant, the means were compared by the Tukey's test at 5\% probability. Regression analysis was applied to the fertilizer concentrations. All statistical analyses were performed using the SISVAR ${ }^{\circledR} 5.3$ statistical software (FERREIRA, 2011).

\section{RESULTS AND DISCUSSION}

According to Table 1, for the variables seedling survival, seedling height, and dry weight of shoot, no significant difference was observed at the doses of 50,100 , and $200 \%$ of fertilizer. This result indicates that there is no need for split application and that the complete concentration can be applied at planting. Conversely, the split application was beneficial at the dose of $400 \%$ of fertilizer. This result is due to the fact that complete fertilizer application at a dose of $400 \%$ caused total mortality of the seedlings; conversely, seedlings had a better reaction with split application. When analyzing the doses of fertilizer within each split application, results are represented by negative and quadratic linear equations, where the highest dose (400\%) provided lower results (Table 1).

The number of leaves did not significantly differ at the doses of 50 and $100 \%$ of fertilizer, and can be entirely applied at planting. For the dose of $200 \%$ of fertilizer, the highest mean (14.75) was obtained with four split applications, not differing from the total application at planting neither from the four split applications. At the dose of $400 \%$, the total fertilizer application at planting caused $100 \%$ mortality of the seedlings, which indicates that this dose needs to be split (Table 1). Similar results were reported for Guzmania lingulata, where fertilizations with $\mathrm{N}, \mathrm{P}, \mathrm{K}, \mathrm{Ca}$ and $\mathrm{Mg}$ did not significantly influence the number of leaves (CHAO-YI; DER-MING, 2008). 
Table 1. Survival (\%), plant height (cm), number of leaves, and dry weight of shoot (mg) of Tillandsia bulbosa seedlings in function of the dose and the fertilizer split application at the acclimatization stage.

\begin{tabular}{|c|c|c|c|c|c|c|}
\hline \multirow{2}{*}{$\begin{array}{l}\text { Split } \\
\text { application }\end{array}$} & \multicolumn{4}{|c|}{ Fertilizer $(\%)$} & \multirow[t]{2}{*}{ Equation } & \multirow{2}{*}{$\begin{array}{l}\mathrm{CV} \\
(\%)\end{array}$} \\
\hline & 50 & 100 & 200 & 400 & & \\
\hline & 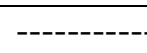 & Surviva & )$---\cdot$ & & & 21.84 \\
\hline 1 & $100.0 \mathrm{a}$ & $100.0 \mathrm{a}$ & $87.5 \mathrm{a}$ & $0.0 \mathrm{~b}^{*}$ & $\mathrm{Y}=127.7174-0.2978 \mathrm{X} ; \mathrm{R}^{2}=91.18 \%$ & \\
\hline 2 & $100.0 \mathrm{a}$ & $100.0 \mathrm{a}$ & $87.5 \mathrm{a}$ & $50.0 \mathrm{a}$ & $\mathrm{Y}=112.5000-0.1500 \mathrm{X} ; \mathrm{R}^{2}=96.28 \%$ & \\
\hline 3 & $100.0 \mathrm{a}$ & $100.0 \mathrm{a}$ & $87.5 \mathrm{a}$ & $62.5 \mathrm{a}$ & $\mathrm{Y}=108.6956-0.1130 \mathrm{X} ; \mathrm{R}^{2}=97.97 \%$ & \\
\hline 4 & $87.5 \mathrm{a}$ & $87.5 \mathrm{a}$ & $100.0 \mathrm{a}$ & $50.0 \mathrm{a}$ & $\begin{array}{l}Y=70.8333+0.3145 X-0.0009 X^{2} ; R^{2}= \\
96.42 \%\end{array}$ & \\
\hline
\end{tabular}

\begin{tabular}{llllll}
\hline & & & & \\
1 & $11.27 \mathrm{a}$ & $11.66 \mathrm{a}$ & $10.28 \mathrm{a}$ & $0.00 \mathrm{~b}^{*}$ & $\mathrm{Y}=14.6771-0.0339 \mathrm{X} ; \mathrm{R}^{2}=89.23 \%$ \\
2 & $10.10 \mathrm{a}$ & $8.50 \mathrm{a}$ & $8.81 \mathrm{a}$ & $5.75 \mathrm{a}$ & $\mathrm{Y}=10.3750-0.0120 \mathrm{X} ; \mathrm{R}^{2}=96.81 \%$ \\
3 & $10.47 \mathrm{a}$ & $11.06 \mathrm{a}$ & $8.81 \mathrm{a}$ & $6.18 \mathrm{a}$ & $\mathrm{Y}=11.6994-0.0136 \mathrm{X} ; \mathrm{R}^{2}=94.05 \%$ \\
4 & $9.48 \mathrm{a}$ & $9.95 \mathrm{a}$ & $11.47 \mathrm{a}$ & $5.22 \mathrm{a}$ & $\mathrm{Y}=7.2750+0.0443 \mathrm{X}-0.0001 \mathrm{X}^{2} ; \quad \mathrm{R}^{2}=$ \\
& & & & & $97.95 \%$
\end{tabular}

Control 10.55

\begin{tabular}{|c|c|c|c|c|c|}
\hline & $--\cdot$ & $-\mathrm{Nu}$ & leaves --. & ----' & \\
\hline 1 & $13.25 \mathrm{a}$ & $14.37 \mathrm{a}$ & $11.00 \mathrm{ab}$ & $0.00 \mathrm{~b}^{*}$ & $\mathrm{Y}=17.3315-0.0409 \mathrm{X}-\mathrm{R}^{2}=92.48 \%$ \\
\hline 2 & $13.00 \mathrm{a}$ & $13.62 \mathrm{a}$ & $8.62 \mathrm{~b}$ & $7.37 \mathrm{a}$ & $\mathrm{Y}=14.0597-0.0181 \mathrm{X}-\mathrm{R}^{2}=81.11 \%$ \\
\hline 3 & $13.25 \mathrm{a}$ & $15.37 \mathrm{a}$ & $11.25 \mathrm{ab}$ & $8.12 \mathrm{a}$ & $\mathrm{Y}=15.3913-0.0180 \mathrm{X}-\mathrm{R}^{2}=82.41 \%$ \\
\hline 4 & $10.50 \mathrm{a}$ & $14.00 \mathrm{a}$ & $14.75 \mathrm{a}$ & $6.87 \mathrm{a}$ & $\begin{array}{l}\mathrm{Y}=7.5208+0.0775 \mathrm{X}-0.0001 \mathrm{X}^{2} ; \quad \mathrm{R}^{2}= \\
97.99 \%\end{array}$ \\
\hline
\end{tabular}

Control 14.75

\begin{tabular}{|c|c|c|c|c|c|}
\hline & ---- Dry & weight of & ot (mg) & & \\
\hline 1 & $321.36 \mathrm{a}$ & $355.88 \mathrm{a}$ & $331.72 \mathrm{a}$ & $0.00 b^{*}$ & $\begin{array}{l}\mathrm{Y}=258.6755+1.4149 \mathrm{X}-0.0051 \mathrm{X}^{2} ; \mathrm{R}^{2}= \\
99.90 \%\end{array}$ \\
\hline 2 & $336.01 \mathrm{a}$ & $298.38 \mathrm{a}$ & $210.79 \mathrm{a}$ & $185.76 \mathrm{a}$ & $\mathrm{Y}=336.5230-0.4201 \mathrm{X} ; \mathrm{R}^{2}=83.69 \%$ \\
\hline 3 & $281.97 \mathrm{a}$ & $401.59 \mathrm{a}$ & $284.15 \mathrm{a}$ & $149.32 \mathrm{a}$ & $\begin{array}{l}Y=297.9152+0.5909 X-0.0024 X^{2} ; R^{2}= \\
76.41 \%\end{array}$ \\
\hline 4 & $298.68 \mathrm{a}$ & $379.61 \mathrm{a}$ & $345.42 \mathrm{a}$ & $113.65 \mathrm{a}$ & $\begin{array}{l}Y=243.8757+1.5030 X-0.0045 X^{2} ; R^{2}= \\
96.31 \%\end{array}$ \\
\hline
\end{tabular}

Control $\quad 300.75$

* Significant difference when compared with the control by the Tukey's test ( $\mathrm{p} \leq 0.05)$; Means followed by the same letters in the columns do not statistically differ by the Tukey's test ( $\mathrm{p} \leq 0.05$ ); Split application: (1) total application at planting; (2) $1 / 2$ at planting, and $1 / 2$ at 80 days after planting (DAP); (3) 1/3 at planting, $1 / 3$ at 50 DAP, and $1 / 3$ at 100 DAP; (4) 1/4 at planting, 1/4 at 30 DAP, $1 / 4$ at 60 DAP, and $1 / 4$ at 120 DAP.

No significant differences were observed between the treatments and the control for all variables analyzed, except for the total application of $400 \%$ of fertilizer, which caused $100 \%$ of seedling mortality (Table 1).

The species used in the present study is epiphyte. The primary function of its roots is the seedling's support. They are usually sensitive to nutrients excess and absorb the elements from the rainwater and particles from the atmosphere through the trichomes (AMARAL et al., 2009). However, their roots may have secondary importance in nutrient absorption from the substrate (DEMATTÉ; VIDAL, 2015). Possibly, the dose of $400 \%$ of fertilizer provided nutrients above ideal content for this species, resulting in plant mortality or reduction of seedling survival (Table 1).

Regarding the anatomical characteristics of the leaves, a significant effect in the fertilizer split application was observed for the analyzed variables. For the vascular bundle area, in general, the highest values were reported at the doses of 100 and $200 \%$ of fertilizer when using three and four split applications (Table 2 and Figure 1). The responses to the doses of fertilizer within each split application are represented by quadratic equations, where the dose of $400 \%$ of fertilizer had inferior results when using all split applications and when compared with the control. At the doses of 100 and $200 \%$, vascular bundle area was observed when compared with the control. The expansion of vascular bundles 
increased the efficiency of the water-carrying capacity and translocation of photoassimilates in the leaves and provided greater support and protection to vascular tissues (VAN DER MERWE et al. 1994; MAGALHÃES et al., 2009). Thus, this expansion may increase the survival capacity and improve seedling development at the acclimatization stage.

Abaxial epidermis thickness varied according to the split application and fertilizer. The lowest means in all the split applications, regarding the doses and the control, were achieved with $400 \%$ of fertilizer. In general, a greater thickness was obtained with $100 \%$ of fertilizer (Table 2 and Figure B1).

For abaxial cuticle thickness, with 50 and $100 \%$ of fertilizer, the highest means were obtained when the fertilized was applied at once at planting and in two split applications. For $200 \%$ of fertilizer, means ranged from 1.27 to $1.32 \mu \mathrm{m}$. At $400 \%$ of fertilizer, a greater abaxial cuticle thickness (1.28 $\mu \mathrm{m})$ was obtained when fertilization was carried out in four split applications, although it did not significantly differ from two split applications. The results of the split applications 1 and 2 are characterized by negative linear equations, where smaller doses allowed greater cuticle thickness. Conversely, the results of the split applications 3 and 4 are represented by quadratic equations, with a greater thicknesses at the dose of $100 \%$ of fertilizer (Table 2).

Table 2. Vascular bundle area $(\mu \mathrm{m})$ and thickness $(\mu \mathrm{m})$ of the abaxial and adaxial epidermis, of the abaxial and adaxial cuticles, of the aquifer and chlorophyll parenchyma, and of the leaf blade of Tillandsia bulbosa, according to the dose and fertilizer split application at the acclimatization stage.

\begin{tabular}{|c|c|c|c|c|c|}
\hline \multirow{2}{*}{$\begin{array}{l}\text { Split } \\
\text { application }\end{array}$} & \multicolumn{4}{|c|}{ Fertilizer $(\%)$} & \multirow[t]{2}{*}{ Equation } \\
\hline & 50 & 100 & 200 & 400 & \\
\hline & \multicolumn{4}{|c|}{--------Área do feixe vascular $\left(\mu \mathrm{m}^{2}\right)$} & \multirow{3}{*}{$\begin{array}{l}Y=1353.8750+174545 X-0.0519 X^{2} ; \quad R^{2}= \\
97.16 \% \\
Y=1992.7916+8.1092 X-0.0262 X^{2} ; \\
98.83 \%\end{array}$} \\
\hline 1 & $2266.5 \mathrm{a}$ & $2282.5 \mathrm{c}$ & $2914.8 \mathrm{a}^{3}$ & $0.0 \mathrm{c}^{*}$ & \\
\hline 2 & $2270.5 \mathrm{a}$ & $\begin{array}{l}2650.5 \\
b^{*}\end{array}$ & $2511.8 \mathrm{~b}$ & $1050.5 b^{*}$ & \\
\hline 3 & $2274.5 \mathrm{a}$ & $3068.8 \mathrm{a}^{3}$ & $2971.5 \mathrm{a}^{3}$ & $1084.3 b^{*}$ & $\begin{array}{l}\mathrm{Y}=1760.0416+14.9851 \mathrm{X}-0.0417 \mathrm{X}^{2} ; \mathrm{R}^{2}= \\
96.72 \%\end{array}$ \\
\hline 4 & $2278.5 \mathrm{a}$ & $2976.5 a^{3}$ & $3065.0 \mathrm{a}^{3}$ & $1523.5 \mathrm{a}^{*}$ & $\begin{array}{l}Y=1729.9166+146881 X-0.0380 X^{2} ; R^{2}= \\
97.42 \%\end{array}$ \\
\hline$n t r$ & & & & & \\
\hline
\end{tabular}

\begin{tabular}{|c|c|c|c|c|c|c|c|}
\hline & \multicolumn{6}{|c|}{-- Abaxial epidermis thickness $(\mu \mathrm{m})$-- } & \\
\hline 1 & $7.25 \mathrm{~b}$ & $8.52 \mathrm{a}^{*}$ & $7.08 \mathrm{a}$ & $0.00 b^{*}$ & $\begin{array}{l}Y=6.6116+0.0239 X-0.0001 X^{2} \\
99.00 \%\end{array}$ & $\mathrm{R}^{2}$ & $=$ \\
\hline 2 & $6.84 \mathrm{~b}$ & $6.14 b^{*}$ & $7.06 \mathrm{a}$ & $5.11 \mathrm{a}^{*}$ & $\begin{array}{l}Y=6.1354+0.0088 X-0.00002 x^{2} \\
75.99 \%\end{array}$ & $\mathrm{R}^{2}$ & $=$ \\
\hline 3 & $8.17 \mathrm{a}$ & $8.75 \mathrm{a}^{*}$ & $6.07 b^{*}$ & $4.75 \mathrm{a}^{*}$ & $\begin{array}{l}Y=9.5454-0.0181 X+0.00001 X^{2} \\
88.21 \%\end{array}$ & $\mathrm{R}^{2}$ & $=$ \\
\hline 4 & $6.14 c^{*}$ & $8.49 \mathrm{a}$ & $6.42 b^{*}$ & $4.72 \mathrm{a}^{*}$ & $\begin{array}{l}Y=6.4629+0.0108 X-0.0004 X^{2} \\
61.16 \%\end{array}$ & $\mathrm{R}^{2}$ & $=$ \\
\hline
\end{tabular}

Control $\quad 7.59$

\begin{tabular}{|c|c|c|c|c|c|c|c|}
\hline & -- Adax & dermis & hickness & um) -- & & & \\
\hline 1 & $5.15 \mathrm{a}^{*}$ & $5.85 \mathrm{ab}$ & $5.26 \mathrm{a}^{*}$ & $0.00 \mathrm{~d}^{*}$ & $\begin{array}{l}Y=4.4450+0.0201 X-0.00007 X^{2} \\
99.78 \%\end{array}$ & $\mathrm{R}^{2}$ & $=$ \\
\hline 2 & $5.39 \mathrm{a}$ & $5.29 \mathrm{c}^{*}$ & $5.23 \mathrm{a}^{*}$ & $5.39 \mathrm{a}$ & Ns & & \\
\hline 3 & $5.09 \mathrm{a}^{*}$ & $6.27 \mathrm{a}^{*}$ & $5.04 \mathrm{a}^{*}$ & $3.11 c^{*}$ & $\begin{array}{l}Y=5.2054+0.0070 X-0.00003 X^{2} \\
86.08 \%\end{array}$ & $\mathrm{R}^{2}$ & $=$ \\
\hline 4 & $4.63 \mathrm{~b}^{*}$ & $5.76 b$ & $5.18 \mathrm{a}^{*}$ & $4.10 b^{*}$ & $\begin{array}{l}Y=4.4608+0.0108 X-0.00003 X^{2} \\
72.50 \%\end{array}$ & $\mathrm{R}^{2}$ & \\
\hline
\end{tabular}

Control $\quad 6.02$

$\begin{array}{llccc}\text {-- Abaxial cuticle thickness }(\mu \mathrm{m}) \text {-- } & & \\ 1.73 \mathrm{a}^{*} & 1.61 \mathrm{ab}^{*} & 1.30 \mathrm{a} & 0.00 \mathrm{c}^{*} & \mathrm{Y}=2.1115-0.0050 \mathrm{X} ; \mathrm{R}^{2}=96.52 \% \\ 1.88 \mathrm{a}^{*} & 1.72 \mathrm{a}^{*} & 1.27 \mathrm{a} & 1.13 \mathrm{ab} & \mathrm{Y}=1.9019-0.0021 \mathrm{X} ; \mathrm{R}^{2}=85.78 \%\end{array}$




$\begin{array}{llllll}3 & 1.29 \mathrm{~b} & 1.48 \mathrm{~b} & 1.25 \mathrm{a} & 1.09 \mathrm{~b} & \begin{array}{l}\mathrm{Y}=1.3558+0.0002 \mathrm{X}-0.000002 \mathrm{X}^{2} ; \\ 4\end{array} \\ 1.37 \mathrm{~b} & 1.42 \mathrm{~b} & 1.32 \mathrm{a} & 1.28 \mathrm{a} & \begin{array}{l}\mathrm{Y} \mathrm{R}^{2}= \\ \mathrm{Y}=1.23 \% \\ 73.48 \%\end{array}\end{array}$

Control 1.31

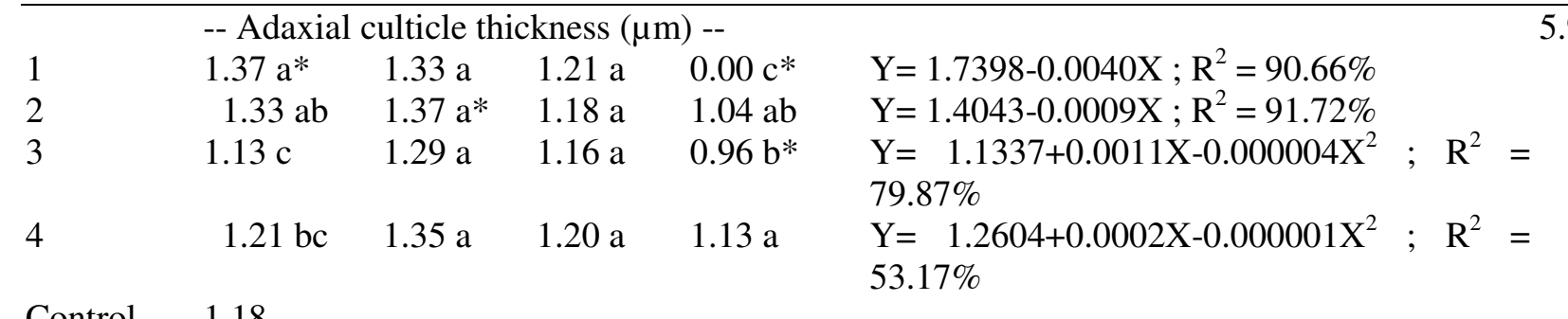

Control 1.18

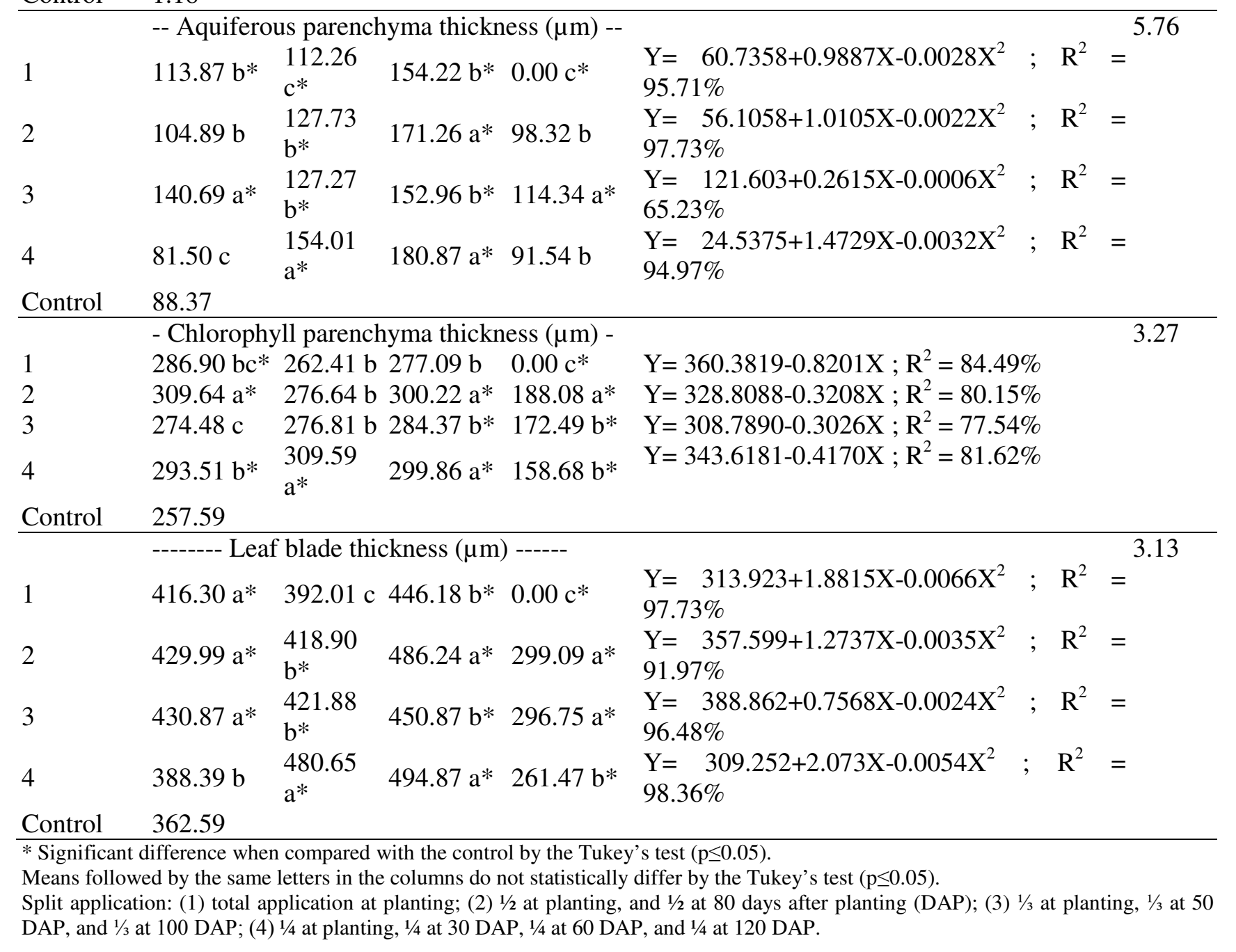


$\mathrm{A} 1$

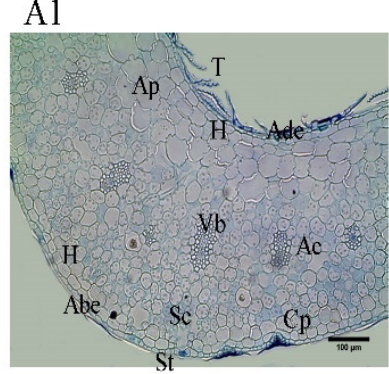

B1

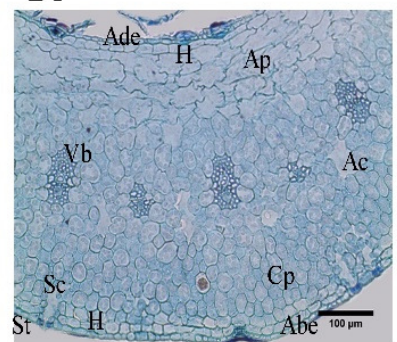

$\mathrm{C} 1$
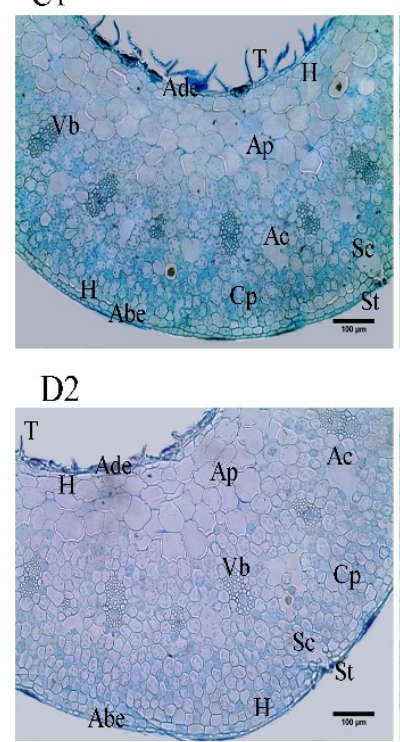

$\mathrm{A} 2$

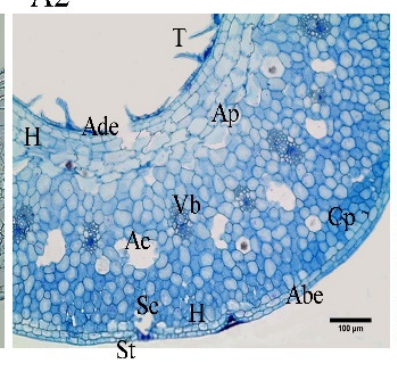

B2

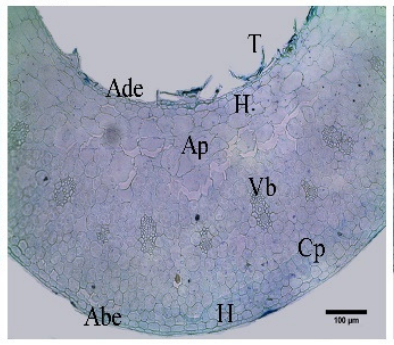

$\mathrm{C} 2$

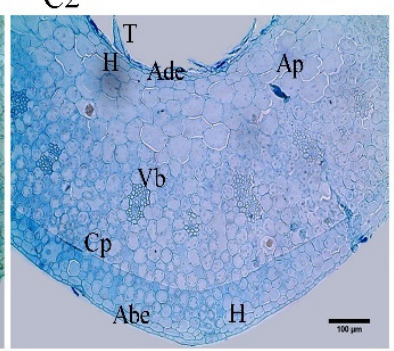

D3

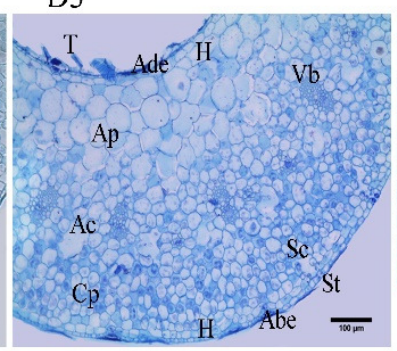

A3

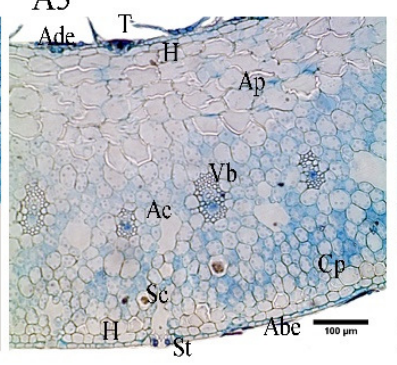

B3

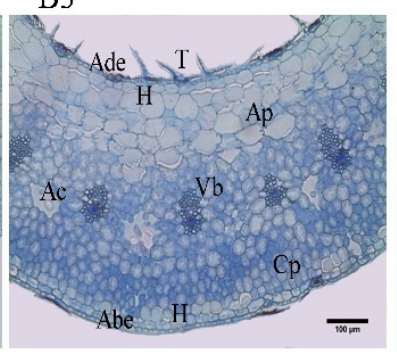

C3

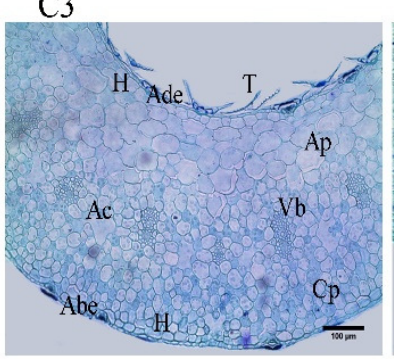

D4

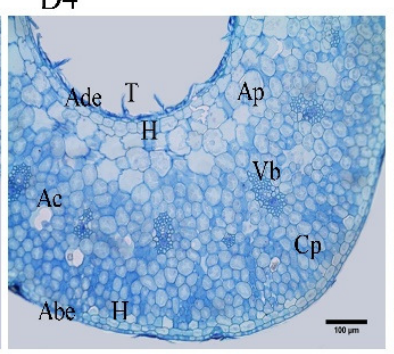

A4

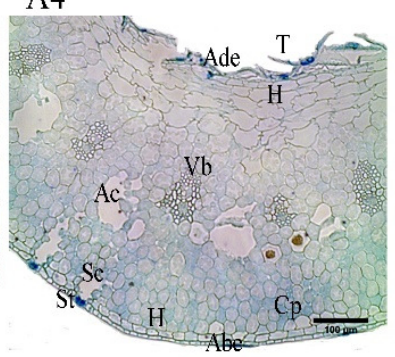

B4

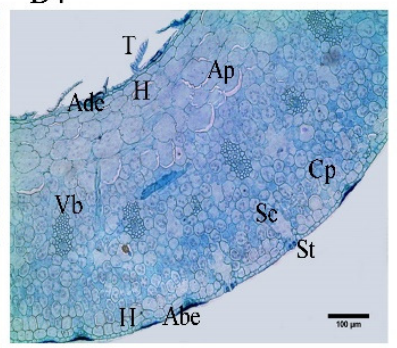

C4

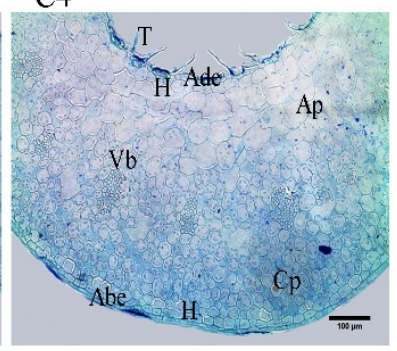

E

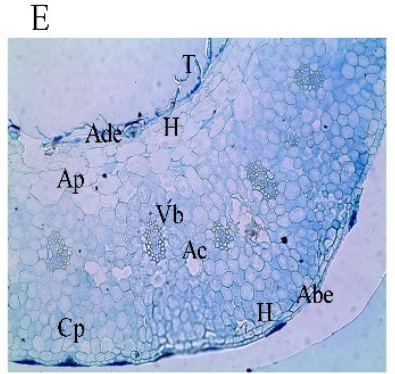

Figure 1. Details of the mesophyll in cross sections of Tillandsia bulbosa leaves taken from seedlings grown with 50 (A), 100 (B), 200 (C), 400\% (D), 0 - control (E) of fertilizer applied in four different periods. (1) Total application at planting; (2) $1 / 2$ at planting and $1 / 2$ at 80 DAP (days after planting); (3) $1 / 3$ at planting, $1 / 3$ at 50 DAP, and $1 / 3$ at 100 DAP; (4) at planting, $1 / 4$ at $30 \mathrm{DAP}, 1 / 4$ at $60 \mathrm{DAP}$, and $1 / 4$ at 120 DAP. Ac = air channel; $\mathrm{Sc}=$ substomatal camera; $\mathrm{Abe}=$ abaxial epidermis; Ade $=$ adaxial epidermis; $\mathrm{St}=$ stomata; $\mathrm{Vb}=$ vascular bundle; $\mathrm{H}=$ hypodermis; $\mathrm{Ap}=$ aquifer parenchyma; $\mathrm{Cp}=$ chlorophyll parenchyma; $\mathrm{T}=$ trichomes; The arrows indicate idioblast with presence of druse.

Better results for adaxial cuticle thickness were reported when the dose of $50 \%$ of fertilizer was applied at once at planting, and in two split applications. For the doses of 100 and $200 \%$ of fertilizer, the means ranged between 1.29 and 1.37 $(100 \%)$ and 1.16 and 1.21 (200\%). When analyzing the doses of fertilizer within each split application, the responses are represented by linear and quadratic equations, where the dose of $400 \%$ provided the lowest thickness values (Table 2 and Figure D1).
Different biotic and/or abiotic stresses, such as nutrient availability, may result in changes in epidermis and leaf cuticle thickness. Seedlings with lower epidermis thickness are more susceptible to the attack by pests and pathogens, as well as to higher transpiration rates, and consequently excessive water loss. Thus, seedlings with greater epidermis and cuticle thickness will have greater chances of survival when transferred to an external environment since the primary functions of these tissues are the protection of the seedlings surface 
and the control of the gas exchanges (CASTRO et al., 2009; JAVELLE et al., 2010).

For aquifer parenchyma thickness, using the doses of $50 \%$ and $400 \%$ of fertilizer, the best results were obtained when using three split applications. For $100 \%$ of fertilizer, a greater thickness was obtained when using four split applications (154.01 $\mu \mathrm{m})$. At a dose of $200 \%$ of fertilizer, split applications $2(171.26 \mu \mathrm{m})$ and $4(180.87 \mu \mathrm{m})$ presented better results (Table 2 and Figure 1). The responses for each split application under the different doses are represented by quadratic equations, where the dose of $200 \%$ of fertilizer provided higher values in relation to the other treatments (Table 2 and Figure C1). In general, a greater thickness was reported at doses of 50, 100, and $200 \%$ of fertilizer, when compared with the control.

A thicker aquifer parenchyma assists in storage capacity and reduction of water loss, making more efficient the use of this resource and providing lower transpiration rate. This tissue also protects the chlorophyll parenchyma against photo-oxidation in environments with high light incidence, limiting the light intensity that reaches the photosynthetic apparatus (PEREIRA et al., 2013).

A thicker chlorophyll parenchyma was observed in seedlings in treatments at the dose of 50 and $400 \%$ of fertilizer using two split applications. For the treatment with $100 \%$ of fertilizer, the best result, $309.59 \mu \mathrm{m}$, was obtained with four split applications. The use of the dose of $200 \%$ of fertilizer in 2 and 4 applications resulted in the greatest thickness (300.22 and 299.86 $\mu \mathrm{m})$. The dose of $400 \%$ of fertilizer had inferior results in all the split applications when compared with the control. For the other doses, higher means were obtained, although some did not differ significantly from the control. The results for the fertilizer doses within each split application are represented by negative linear equations, where smaller thickness was obtained at higher doses (Table 2).
A thicker chlorophyll parenchyma increases the light diffusion capacity in the leaf, and consequently the efficiency in the use of this resource, probably favoring the photochemical stage of photosynthesis and influencing seedling's ability to assimilate carbon (VOGELMANN; GORTON, 2014). These factors may increase the photosynthetic capacity of the seedlings, reducing the stress caused by the transfer from the heterotrophic to autotrophic condition at the acclimatization stage.

The highest values of leaf blades (446.18 to $494.87 \mu \mathrm{m}$, ) were observed in the treatments with $200 \%$, and the lowest values (0.00 to $299.09 \mu \mathrm{m})$ were reported in the treatment with $400 \%$ (Table 2). Leaf blade represents the main photosynthetic tissue of the plant, and thus, probably, a greater thickness can provide greater photosynthetic capacity, favoring $\mathrm{CO}_{2}$ diffusion (TOMÁS et al., 2013).

\section{CONCLUSIONS}

Fertilization did not significantly influence the development of $T$. bulbosa seedlings during the acclimatization stage.

The doses of 50, 100, and $200 \%$ provided a greater thickness of chlorophyll parenchyma, aquifer parenchyma, and leaf blade.

T. bulbosa can be acclimatized without fertilizer application.

\section{ACKNOWLEDGMENTS}

The authors thank CNPq (Conselho Nacional de Desenvolvimento Científico e Tecnológico), FAPITEC-SE (Fundação de apoio à pesquisa e à inovação tecnológica do Estado de Sergipe), and CAPES (Coordenação de Aperfeiçoamento de Pessoal de Nível Superior) for their financial support of this study.

RESUMO: As bromélias são conhecidas mundialmente por seu potencial ornamental. No Brasil, as espécies de Tillandsia podem ser encontradas na Mata Atlântica, Floresta Amazônica e campos rupestres. O objetivo deste trabalho foi verificar a influência de adubação com nitrogênio, fósforo e potássio em plântulas micropropagadas de Tillandsia bulbosa, na fase de aclimatização e na sua anatomia foliar. O experimento foi implantado em delineamento inteiramente casualizado, em esquema fatorial $4 \times 4+1$, utilizando como substrato a mistura de pó de coco: húmus de minhoca: areia (2:1:1). Ureia, super fosfato simples e cloreto de potássio foram utilizados como fontes de nitrogênio, fósforo e potássio, nas proporções de 50, 100, 200 e 400\% da dose recomendada. As doses foram distribuídas em quatro aplicações, testando aplicação total no plantio (1); $1 / 2$ no plantio e $1 / 2$ aos 80 DAP (2); $1 / 3$ no plantio, $1 / 3$ aos 50 DAP e $1 / 3$ aos 100 DAP (3) e $1 / 4$ no plantio, $1 / 4$ aos 30 DAP, $1 / 4$ aos 60 DAP e 1/4 aos 120 DAP (4), e uma testemunha (sem adubação). Foi realizado o estudo anatômico das folhas aos 180 dias. A adubação não influenciou significativamente o desenvolvimento das plântulas durante a aclimatização. As doses de 50, 100 e 200\% proporcionaram maior espessura de parênquimas clorofiliano e aquífero e do limbo foliar. A aclimatização de Tillandsia bulbosa pode ser realizada sem a necessidade de adubação. 
PALAVRAS-CHAVES: Bromeliaceae. Cultura de tecidos. Adubo. Anatomia foliar

\section{REFERENCES}

AMARAL, T. L.; JASMIM, J. M; NAHOUM, P. I; FREITAS, C. B; SALES, C. S. Adubação nitrogenada e potássica de bromeliáceas cultivadas em fibra de coco e esterco bovino. Horticultura Brasileira, Brasília, v. 27, n. 3, p. 286-289, 2009. http://dx.doi.org/10.1590/S0102-05362009000300004.

BATAGIN, K. D.; BATAGIN, K. D.; ALMEIDA, C. V.; TANAKA, F. A. O.; ALMEIDA, M. Alterações morfológicas foliares em abacaxizeiro cv IAC "Gomo-de-mel" micropropagados e aclimatizados em diferentes condições de luminosidade. Acta Botânica Brasílica, Brasília, v. 23, n. 1, p. 85-92, 2009.

http://dx.doi.org/10.1590/S0102-33062009000100011.

BENZING, D. H. Vegetative structure. In: BENZING, D.H. (Ed.). Bromeliaceae: profile of an adaptive radiation. Cambridge: Cambridge University Press, 2000. p. 19-77.

http://dx.doi.org/10.1017/CBO9780511565175.004.

CASTRO, E. M.; PEREIRA, F. J.; PAIVA, R. Histologia Vegetal: estrutura e função de órgãos vegetativos. Lavras: UFLA, 2009. 234 p.

CHAO-YI, L.; DER-MING, Y. Potassium nutrition affects leaf growth, anatomy, and macroelements of Guzmania. Hortscience, v. 43, n. 1, p. 146-148. 2008.

DEMATTÊ, M. E. S. P.; VIDAL, U. Cultivo de Tillandsia geminiflora Brongn. em diferentes substrates. Ornamental Horticulture, Campinas, v. 21, n. 1, p. 119-123, 2015.

http://dx.doi.org/10.14295/rbho.v21i1.784.

FERREIRA, D. F. Sisvar: a computer statistical analysis system. Ciência e Agrotecnologia, Lavras, v. 35, n. 6 , p. 1039-1042, 2011. http://dx.doi.org/10.1590/S1413-70542011000600001.

FIORATO, L. O gênero Tillandsia L. (Bromeliaceae) no estado da Bahia, Brasil. 2009. 123f. Dissertação (Mestrado em Biodiversidade Vegetal e Meio Ambiente) Instituto de Botânica de São Paulo-SP, 2009.

JAVELLE, M.; VERNOUD, V., ROGOWSKY, P. M.; INGRAM, G. C. Epidermis: the formation and functions of a fundamental plant tissue. New Phytologist, v. 189, n. 1, p. 17-39, 2010.

http://dx.doi.org/10.1111/j.1469-8137.2010.03514.x.

JOHANSEN, D. A. Plant microtechnique. New York: Mc Graw Hill, 1940. 523 p.

http://dx.doi.org/10.1111/j.1095-8339.1995. tb00452.x.

KRAUS, J. E.; ARDUIM, M. Manual básico de métodos em morfologia vegetal. Rio de Janeiro: Seropédica, 1997, $198 \mathrm{p}$.

LONE, A. B.; TAKAHASHI, L. S. A.; FARIA, R. T. de; ASSIS A. M. de; UNEMOTO, L. K.

Desenvolvimento vegetativo de orquídeas submetidas a diferentes formulações de macronutrientes e frequências de adubação durante a fase de aclimatização. Semina: Ciências Agrárias, Londrina, v. 31, n. 4, p. 895-900, 2010. http://dx.doi.org/10.5433/1679-0359.2010v31n4p895.

MAGAlHÃES, P. C; SOUZA, T. C.; PEREIRA, F. J.; CASTRO, E. M.; PARENTONI, S. N. Anatomia foliar nos sucessivos ciclos de seleção do milho Saracura sob alagamento intermitente do solo. Minas Gerais: Boletim de Pesquisa e Desenvolvimento / Embrapa Milho e Sorgo, 2009. 27 p. 
MARTINELLI, G.; VIEIRA, C. M.; GONZALEZ, M.; LEITMAN, P.; PIRATININGA, A.; COSTA, A. F.; FORZZA, R. C. Bromeliaceae da Mata Atlântica brasileira: lista de espécies, distribuição e conservação. Rodriguésia, Rio de Janeiro, v. 59, n. 1, p. 209-258, 2008.

MURASHIGE, T.; SKOOG, F. A revised medium for rapid grow than bioassays with tobacco tissue cultures. Physiologia Plantarum, Helsinki, v. 15, n. 43, p. 473-497, 1962. http://dx.doi.org/10.1111/j.13993054.1962.tb08052.x.

OLIVEIRA, K. S. de; ALOUFA, M. A. I. Influência de substratos na germinação de sementes de Anadenanthera colubrina (Vell.) Brenan em condições de casa de vegetação. Revista Árvore, Viçosa, v. 36, n. 6, p. 1073-1078, 2012. http://dx.doi.org/10.1590/S0100-67622012000600008.

PEREIRA, T. A. R; SILVA, L. C.; AZEVEDO, A. A.; FRANCINO, D. M. T.; COSER, T. S.; PEREIRA, J. D. Leaf morpho-anatomical variations in Billbergia elegans and Neoregelia mucugensis (Bromeliaceae) exposed to lowand high solar radiation. Botany, Ottawa, v. 91, n. 6, p. 327-334, 2013. https://doi.org/10.1139/cjb-20120276.

PROENÇA, S. L.; SAJO, M. G. Anatomia foliar de bromélias ocorrentes em áreas de cerrado do Estado de São Paulo, Brasil. Acta Botanica Brasilica, Brasília, v. 21, n. 3, p. 657-673, 2007.

http://dx.doi.org/10.1590/S0102-33062007000300013.

RIBEIRO, M. C.; METZGER, J. P.; MARTENSEN, A. C.; PONZONI, F.; HIROTA, M. M. Brazilian Atlantic forest: how much is left and how is the remaining forest distributed? Implications for conservation. Biological Conservation, Washington, v. 142, n. 6, p. 1141-1153, 2009. https://doi.org/10.1016/j.biocon.2009.02.021.

SIMPSON, M. G. Plant systematics. Elsevier: Amsterdam, 2006, p. 589.

TILL, W. Tillandsioideae. In: BENZING, D. H. (Ed.). Bromeliaceae: profile of an adaptative radation. Cambridge University, 2000. p. 555-569.

TOMÁS, M.; FLEXAS, J.; COPOLOVICI, L.; GALMÉS, J.; HALLIK, L.; MEDRANO, H.; RIBASCARBÓ, M.; TOSENS, T.; VISLAP, V.; NIINEMETS, U. Importance of leaf anatomy in determining mesophyll diffusion conductance to $\mathrm{CO}_{2}$ across species: quantitative limitations and scaling up by models.

Journal of Experimental Botany, London, v. 64, n. 8, p. 2269-2281, 2013. https://doi.org/10.1093/jxb/ert086.

VAN DER MERWE, A. M.; VAN DER WALT, J. J. A.; MARAIS, E. M. Anatomical adaptations in the leaves of selected fynbos species. South African Journal of Botany, v. 60, n. 2, p. 99-107, 1994.

https://doi.org/10.1016/S0254-6299(16)30639-1.

VOGELMANN T, GORTON H. Leaf: Light Capture in the Photosynthetic Organ. In: The Structural Basis of Biological Energy Generation. Netherlands: Springer Netherlands, 2014. p. 363-377.

https://doi.org/10.1007/978-94-017-8742-0_19. 